\title{
Life Cycle Cost Calculation at the Transport Company in the Supply of Production of Wooden Houses - Case Study
}

\author{
Marek Potkány ${ }^{1, *}$, Miloš Hitka ${ }^{1}$, and Lucia Krajčírová $^{1}$ \\ ${ }^{1}$ Technical University in Zvolen, T. G. Masaryka 24, 96053 Zvolen, Slovakia
}

\begin{abstract}
A correct information manager's decision-maker database is a very important element that substantially affects its success. This article presents the potential of using the methodology of life cycle cost calculation in the conditions of a transport company that focuses on the logistic supply of wood-housing producers. The problem is presented through a case study and addresses the decision-making aspect of the decision about acquisition of the transport vehicle. This decision uses time value indicators, inflation rates, average rate of profitability of industry and life cycle costs. Due to the short life cycle of the analyzed period, it was not necessary to consider the ergonomic requirements resulting from the trend of anthropometric dimensions growth.
\end{abstract}

\section{Introduction}

The business activity is accompanied by a number of decisions - both operative and strategic level. One of the strategic tools that can be used in this area is Life Cycle Cost calculation. Managers in their activities must also deal with various strategic decisions. Life Cycle Cost (LCC) Calculation is a method that is one with strategic decision-making tools. The main goal of this article is to present the use of LCC methodology in the decision making of the transport company, the object of which is the supply of building materials to the producers of wooden houses in Slovakia.

\section{Theoretical backgrounds}

Many authors of studies, like Popesko and Papadaki, but also Šoljaková, Wagner and Petřík are concerned with the calculation of life cycle costs at the practical conditions. In their work, they are associated with the performance of the enterprise and talking about it as a concept of economic accounting [1-4]. According to the author, it is suitable for complete project management, control and planning and evaluation of investment projects. This calculation shows all costs and revenues of the project during its economic life cycle. For corporate governance, LCC is an important source of information. By using this method, the company knows how much the cost has actually been incurred at all stages of the life

*Corresponding author: potkany@tuzvo.sk 
cycle, from acquisitions, through operating to retirement. The main task of the LCC is to optimize all costs over the entire economic life of the project without losing its overall performance.

According to Šoljaková, which states, that it is also considering the costs in the preproduction phase and the stages that are connected with the end of the production cycle [2]. Crespo Márquez et al state, that a life cycle cost analysis calculates the cost of an asset for its entire life span (Figure 1).

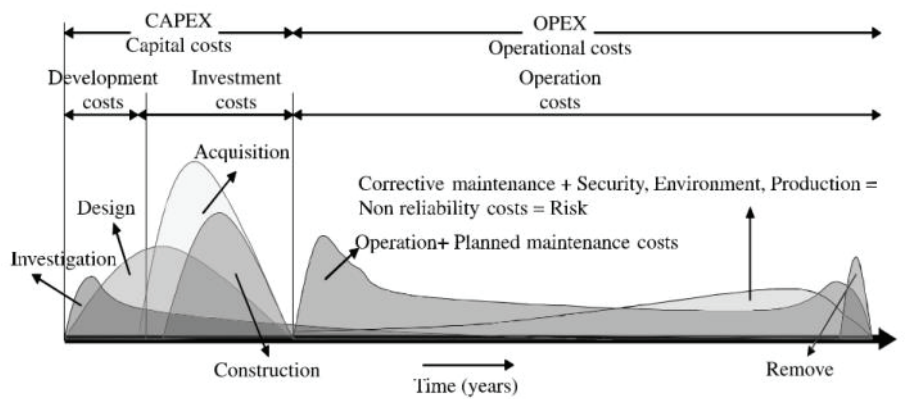

Fig. 1. Life cycle cost analysis. Source: [5]

According to Šoljaková, which states, that the LCC can be expressed as a calculation of the partial or the entire evaluated period. One of the parameters that are the basis for its compilation is the exact definition of the life cycle length [2]. For the LCC application, besides the cycle length itself, it is necessary to know the level of the discount rate, the rate of price growth and the interest rate. According to Zhang and Yuan the standard discount rate is determined by the interest rate and the rate of inflation [6].They state in their work, that life cycle of steel bridge deck pavement is often cannot reach the designed working life, taking 20 years as life cycle in the consideration of actual use situation of steel bridge deck pavement. Standard discount rate is decided by interest rate and inflation rate, discount rate $(\mathrm{I})=$ (interest rate inflation rate) $/(1+$ the inflation rate). The relevant studies have shown that discount rate is between $3 \%$ and $5 \%$ usually.)

LCC finds its application in various transport areas [7], construction [8], the automotive industry [9]. It is linked to the area of environment and construction [10].

According to Stefko and Reinprecht, the wooden house is a construction work, the main supporting structure of which is made of wood, wood elements and wood-based materials. It is a wider concept [11]. It is not just the wooden structure itself. This, however, always forms the supporting part of the wooden house.A frame construction system is simple and does not require a great deal of mechanisation. The object is completely fitted on the building site [12]. A level surface is made on the building site (production-assembly plate). on which the building walls are made. The prepared walls are erected and fitted into the object foundations. The walls covered with wide area materials provide stability and strength and they can also be reinforced using diagonals embedded into the wall mullions.

\section{Methods}

Petković et. al. states that at the decision about implementing of investment project, the terms net present value (NPV) and net future value (NFV) are used [13]. According to the authors, net present value is defined by the sum of discounted values of individual concepts in the flow, where each term is discounted to a common reference date. According to Rossi et. al. the net future value measures the profitability at the end of the planning horizon compared to what might have been gained by investing elsewhere [14]. The discount rate is 
used for discounting the cashflow to the present. The NPV of the estimated cost over the planning horizon is the discounted value of the NFV to the present.

According to Rossi et. al. this method is very often used in the conditions of various industries to decide on the feasibility of projects. It often uses uncertain information and needs to be aware of the cost risk that can influence the analysis [15]. Spickova and Myskova state, that LCC method calculates both present and future value of discounted cash flow [16]. Authors writing that Net Present Value is the basic tool for comparison of the money values in the different times. The LCC application itself can cause some problems. These may occur mainly according to in the process of unification of individual stages of the investment project [17]. If a project is judged by discount techniques, is the solution of transforming all cash flows into real cash flows [18, 19]. Armendariz-Lopez et. al. used in their study to take account of the value of money in time for determining the payback period [20].

This paper takes into account the currency value over time as an economic indicator for the financial evaluation of projects, in order to consider the payback period. The net present value requires the net cash flow. The resulting value is deducted from the initial net investment.

Fourie and Tendayi argue that life-cycle cost analysis basically takes into account all the costs that will be incurred sometime in the future, so the cost of a particular decisionmaking place must be avoided [7]. The decisive point is known as the present value. The following information is used to the methodology of LCC for decision-making database:

- a project lifespan,

- dicount rate,

- capital equipment cost for the maintenance and operational calculations.

Heralová state, that there are several approaches to the LCC application [21]. One is a way of using NPV. In principle, it is necessary to calculate the initial cost of acquisition. Another is to use a stochastic approach where inputs are considered as random variables with assigned probability density functions. There is also the possibility of using a deterministic approach. This is based on an expert estimate of input values from past periods supplemented by a sensitivity analysis.For the conditions of our case study, the total lifecycle costs will be calculated according to the formula (1).

$$
L C C=\text { acquisition price }+ \text { operating cost } \times R B F \pm\left(R P \times \frac{1}{(1+r)^{n}}\right)
$$

where:

LCC - the sum of the life cycle cost at the present value,

$\mathrm{RBF}$ - discount factor for operating costs,

$\mathrm{RP}$ - residual price,

$\mathrm{r}$ - discount rate,

$\mathrm{n}$ - the length of the analysis period.

$\mathrm{RBF}$ is a discount factor (Rentenbarwertfaktor), which works with the discount rate indicator (r) and the length of the analyzed period (n). By the literature source [22] it can be determined by the formula (2).

$$
R B F=\frac{(1+r)^{n}-1}{(1+r)^{n} \times r}
$$

For the determination of the RBF factor, we used the interest rate calculated by the relationship reported by Petř́k [4], which is also reported in study Baum et. al. [23], where we took into account the level of inflation (i) and the average rate of profitability of industry (p) determined by formula 3 . 


$$
\text { discount rate }(r)=[(1+p) \div(1+i)-1] \times 100
$$

We used the following relationships to determine the cost of each cost item. We have taken into account fuel coststhe average consumption (AC) of each vehicle for the previous period, the expectancy distances $\left(\sum \mathrm{km}\right)$ and diesel price for current period/liter (DP/l) (formula 4).

$$
\text { fuel cost }=\frac{\left(\frac{A C}{100} \mathrm{~km} \times \sum \mathrm{km}\right)}{100} \times D P
$$

The engine oil cost, we take into accountof oil change interval (I - 50,000 km), oil tank volume $\left(\mathrm{O}_{\mathrm{v}}-38 \mathrm{l}\right)$ and actual engine oil price (EOP - $\left.€ / 1\right)$ (formula 5). Cost of tires depends from price of tires (PT) in their number (n) and tires change payments $\mathrm{TCH}$. Also from tires life $\left(\mathrm{T}_{1 / \mathrm{km}}\right)$ and the number of kilometers driven $\left(\sum \mathrm{km}\right)$ (formula 6$)$.

$$
\begin{gathered}
\text { engine oil costs }=\frac{(O v \times E O P)}{I} \\
\text { cost of tires }=\frac{(P T \times n)+T C H}{T_{l / k m}} \times \sum k m
\end{gathered}
$$

Maintenance costs include the costs associated with regular replacement of tires, oils, filters, lubricants, spare parts, unsupervised inspections and additional costs. On the acquisition of new mean of transport, these costs foresee lower level versus used mean of transport. The operating costs included insurance cost, motor vehicle tax, technical and emission control and highway toll. In the first year, the cost of registering a motor vehicle was also included in their total amount. For operational costs, we consider the rental office cost, as well as parking cost of vehicles because our company rents. This group also included administrative costs, energy and telecommunication costs. Compensation costs (liquidation cost) were also included in the life cycle cost calculation. A new vehicle is considered to sell it at a residual price of $20 \%$ of the entry price. The used vehicles are considered the cost of liquidation in the amount of $3,000 €$. In the framework of the analysis, the residual price shows a positive share in relation to the cost of life cycle and disposal costs shows the negative share to the cost of life cycle.

\section{Application of LCC - case study}

The subject of our case study is a transport company that focuses on logistic supply to the Slovak producers of wooden houses. The most commonly transported materials are spruce / fir wood, OSB boards, insulating materials, material needed to make perimeter walls of column construction, roof construction, etc. The most commonly transported materials are spruce/fir sawn timber, OSB boards, insulating materials, material needed to make perimeter walls of column construction, roof construction, etc. Decision-making role is based on an assessment of alternatives to the acquisition of new means of transport. The options are as follows:

- $1^{\text {st }}$ alternative: acquisition of new semi-trailer unit in acquisition price $92,000 €$,

- $2^{\text {nd }}$ alternative: acquisition of used semi-trailer unit in acquisition price 51,000 $€$. 
In our case, the lifetime of both vehicles was set for a period of 6 years. Since the cost item depreciation does not represent an expense for the enterprise, we did not count the operating costs.

In our forecast, we calculate the mileage of $110,000 \mathrm{~km} /$ year. The average fuel consumption for the new semi-trailer is $271 / 100 \mathrm{~km}$, and $351 / 100 \mathrm{~km}$. Wage costs represent the sum of the gross wage ( $3.5 €$ /hour) and also the statutory social security and health insurance company contributions. We expect the driver to work on average 200-220 hours per month.

Total operating costs in the first year represent81,780.97 $€$ at the $1^{\text {st }}$ alternative and $93,458.97 €$ at the $2^{\text {nd }}$ alternative. In the next years, they are achieving values $81,621.97 €$ a $93,299.97 €$.

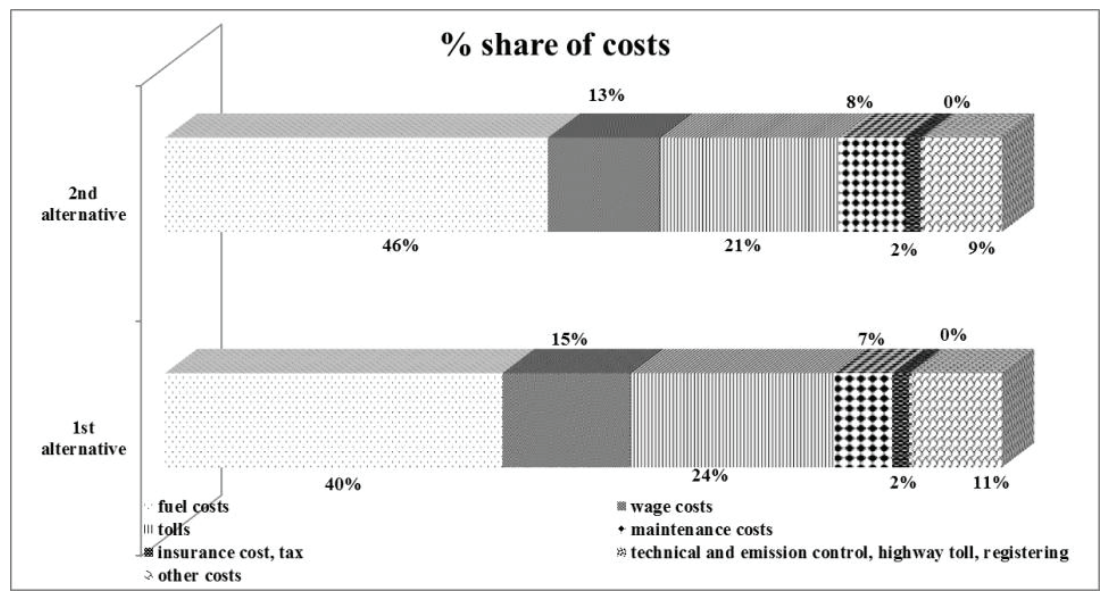

Fig. 2.The share of individual groups of costs for each alternative. Source: authors

The share of costs (Figure 2) is roughly the same level in both cases. The largest share of operating costs are expenses in connection with the procurement of fuel, wages and tolls.

For the determination of life cycle costs, the following data were used in the methodology:

- $\quad$ inflation rate $\mathrm{i}=1.1 \%$

- $\quad$ average rate of profitability of industry $\mathrm{p}=4.3 \%$

- $\quad$ RBF factor $\doteq 5.388$

- $\quad 1^{\text {st }}$ alternativeresidual price $-20 \%$ from acquisition price

- $\quad 2^{\text {nd }}$ alternative liquidation cost $+3,000 €$

Based on the results, we can state that by using the relationship (1) we have determined the value of the lifecycle cost for the new vehicle $\left(1^{\text {st }}\right.$ alternative) at over $516,000 €$. For $2^{\text {nd }}$ alternative, using the LCC methodology, we received a cost level 556,000 €.

$$
\begin{aligned}
& \mathrm{LCC}^{\text {st }} \text { alternative }=92,000+81,621.97 \times 5.388-18,400 \times(1.03165)^{-6} \doteq 516,500 € \\
& \mathrm{LCC} 2^{\text {nd }} \text { alternative }=51,000+93,299.97 \times 5.388+3,000 \times(1.03165)^{-6} \doteq 556,200 €
\end{aligned}
$$

Thus, we can conclude that the initial higher investment in the acquisition of new vehicle is disadvantageous for the company just beginning. Changing the situation and reducing the total cost of the first alternative will occur after the first year of potential use of the vehicles. These conclusions are presented in Figure 3. Our recommendations are, despite the higher acquisition price, use of the possibility of using $1^{\text {st }}$ alternative. 


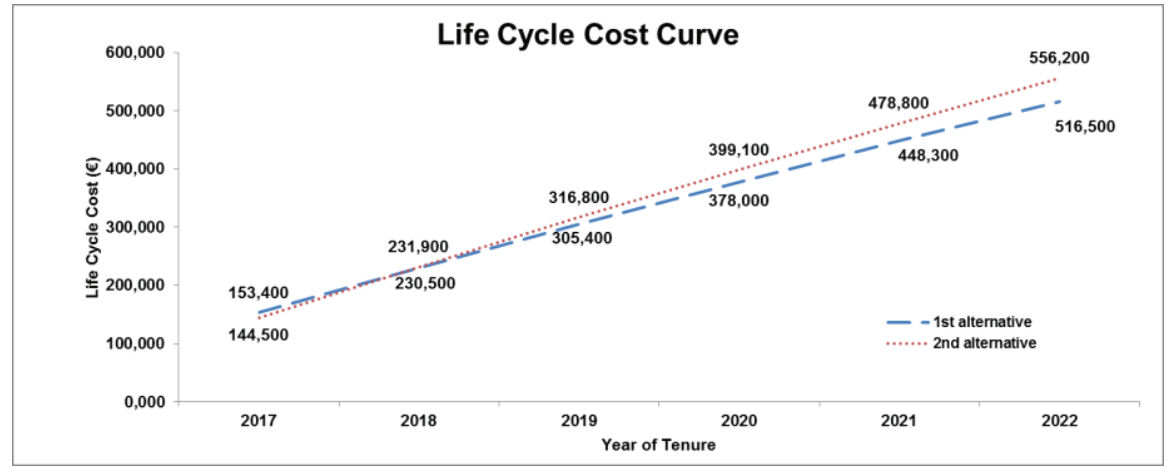

Fig. 3. LifeCycleCostCurve. Source: authors

\section{Conclusion}

Life Cycle Cost calculation is an important tool for managerial decision-making. Its importance is based on the cost quantification across the lifecycle of the cost object at the applied time value of money, which considers the level of inflation rate and the current interest rate. The aim of this calculation is to provide the user important information for the right decision in terms of strategy. For decisions of that type, information is important, which should be accompanied by the minimum level of allocated costs. In this case study, we present an approach that is based on selecting the most appropriate alternative to acquisitions of the transport vehicle at the conditions of assumed purchase price level, the 6-year life span, the inflation rate $1.1 \%$ and the average rate of profitability of industry 4.3 $\%$. The presented approach is based on the business reporting approach in terms of capturing all real costs and revenues and their managerial clarity.

The paper is a partial result of the grant scientific project VEGA No.1/0320/17 Economic and Social Context of European 20/20/20 Targets from the Viewpoint of Economy Low-energy Houses and project APVV 16-02-97 Updating of anthropometric database of Slovak population.

This paper is supported by the research project "From horse-drawn railway to intermodal transport" within Visegrad Fund.

\section{References}

1. B. Popesko, Š. Papadaki, Moderní metody řizení nákladi̊. Jak dosáhnout efektivního vynakládání nákladů a jejich snižení, 264 p. (2016)

2. L. Šoljaková, Strategicky zaměrené manažerské účetnictví, 206 p. (2009)

3. J. Wagner, Měreni výkonnosti. Jak měřit, vyhodnocovat a využivat informace o podnikové výkonnosti, 256 p. (2009)

4. T. Petřík, Procesni a hodnotové ř́zení firem a organizaci - nákladová technika a komplexní manažerská metoda: ABC/ABM (Activity Based Costing/Activity Based Management), 911 p. (2007)

5. A. Crespo Márquez, P. Moreu de León, J. F. Gómez Fernández, C. Parra Márquez, M. López Campos, Journal of Quality in Maintenance Engineering 15, 167 (2009)

6. D. Zhang, F. Ye, J. Yuan, Procedia Social and Behavioral Sciences 96, 785 (2013) 
7. C.J. Fourie, T.G. Tendayi, South African Journal of Industrial Engineering 27, 142 (2016)

8. K.K. Lawania, W.K. Biswas, Clean Technologies and Environmental Policy 18, 2419 (2016)

9. S. Kara, W. Li, N. Sadjiva, Procedia CIRP 61, 767 (2017)

10. B. Grzyl, E. Miszewska-Urbańska, M. Apollo, E3S Web of Conferences 17 (2017)

11. J. Štefko, L. Reinprecht, Dřevěné stavby, konstrukce, ochrana a údržba, 196 p. (2004)

12. J. Štefko, R. Soyka, Wooden buildings, 124 p. (2013)

13. D. Petković, S. Shamshirband, A. Kamsin, M. Lee, O. Anicic, V. Nikolić, Revewable and Sustainable Energy Reviews 57, 1270 (2016)

14. B. Rossi, S. Marquart, G. Rossi, Journal of Environmental Management 197, 41 (2017)

15. L. Kirkwood, E. Shehab, P. Baguley, A. Starr, Procedia CIRP 38, 245 (2015)

16. M. Spickova, R. Myskova, Procedia - Economics and Finance 34, 337 (2015)

17. B. Král et al. Manažérské účetnictví 3, 660 p. (2012)

18. F. Nemec, S. Lorincová, M. Hitka, L. Turínská, Nase more 62, 131 (2015)

19. M. Pavlíčková, K. Teplická, Acta Montanistica Slovaca 19, 59 (2014)

20. J.F. Armendariz-Lopez, A. Luna-Leon, M.E. Gonzalez-Trevizo, A.P. Arena-Granados, G. Bojorquez-Morales, Renewable Energy 87, 564 (2016)

21. R.S. Heralová, Procedia Engineering 85, 454 (2014)

22. Lebenszykluskostenrechnung, Available online: https://www.f08.thkoeln.de/imperia/md/content/personen/professoren/schmieder_matthias/controlling/loe sung_lebenszykluskostenrechnung.pdf (2013)

23. H.G. Baum, A.G. Coenenberg, E. Günther, Betriebliche Umweltökonomie in Fällen. Band I: Anwendung betriebswirtschaftlicher Instrumente, Available online: https://books.google.sk/books?id=hNedCgAAQBAJ\&pg=PA256\&lpg=PA256\&dq=Le benszykluskosten+Break-Even-

Time\&source=bl\&ots=y6ondKquN0\&sig=2P5CUGpRAcBFoxJQjSATTiNY8Ds\&hl= sk\&sa $=$ X\&ved=0ahUKEwjtq6KHssfKAhVIw3IKHfGaCQwQ6AEIGjAA\#v=onepage $\& \mathrm{q}=\mathrm{LCC} \& \mathrm{f}=$ false $(2017)$ 